\title{
The data imperative for web business: A brief overview
}

Received: 7th August, 2000

\begin{abstract}
Neal Rimay-Muranyi
is a director of The Database Group. He joined the company in September 1993 as sales and marketing director. With a background of seven years in the traditional roles of product manager through to marketing manager with subsidiaries of Booker, he then moved into the agency arena, working for three years as the Board Account Director responsible for bringing direct marketing to the agency's client roster. During the past nine years he has applied these experiences to the database marketing sector, with a major emphasis on information based marketing and CRM solutions as consultancy and marketing director with The Database Group, dealing with clients from the automotive, fmcg, publishing and tourism sectors.
\end{abstract}

\section{Simon Lawrence}

is senior partner in the marketing data consultancy Information Arts. His career in direct marketing spans ten years, the first part of which he spent with information owner and marketing services company TDS Ltd. In 1997 he joined Emap Business Communications (EBC) as General Manager of its Direct Marketing Division with a remit to develop the business into a full service marketing information services provider. In April 1999 he formed Information Arts to satisfy a need in the market for an independent and results-orientated business-to-business marketing data specialist.

\begin{abstract}
The pervading myth that every dotcom is an easy and financially accessible enterprise is a dangerous notion and one in which the issues of data and database management have been crucially disregarded. In the wake of media hype over dotcom downfall Internet businesses must acknowledge the fundamental role of data in determining and managing their customers' expectations.

The challenges which web businesses face, issues such as logistics, permission marketing, geodemographics and personalisation, all necessitate a mature and reliable fulfilment infrastructure in order that they can 'level peg' with their offline counterparts.

The authors accentuate the need for online businesses to look to their databases to salvage casualties and state that the failure of some dotcoms lies in the way these companies are run.
\end{abstract}

Neal Rimay-Muranyi The Database Group Ltd, Colston Centre, Colston Avenue, Bristol BS1 4UH. Tel: 0117918 3500; Fax: 01179183501

\section{INTRODUCTION}

Too many myths now abound about doing business on the Internet. It is said that 'dotcoms' have no baggage to weigh down their rapid advance, compared to their bricks and mortar equivalents. It is also said that customer self-service and order tracking is straightforward over the web. Most dangerously, some people maintain that dotcoms can consistently underprice their traditional counterparts because it is so much 'cheaper to do business online'.

The result is a general feeling that online business will work on a shoestring
- apart, that is, for the advertising millions which need to be spent to get people to visit and use the site in the first place. Nothing could be further from the truth. First, under-invested web business will inevitably fail, usually fairly quickly. Secondly, investment has to be put into the right areas, in the right order, or companies will find themselves building on quicksand and achieving the same result as if they had not invested at all. This paper aims to cover some key data-based issues, illustrating how data and database management are fundamental to successful Internet business. 


\section{LOGISTICS}

It is true that dotcom business has not had a very successful public profile recently. The experience (or inexperience) at boo.com is starting to give the lie to this ingrained myth. And, of course, some media commentators have been salivating over the moribund share price of lastminute.com. There is, however, absolutely no reason why clothes retailing or last minute bargains should not be fantastic online business successes, if they are properly run.

Perhaps the first, and most important, data-based subject to touch on is logistics. It is noticeable that virtually all traditional mail order businesses have a web/e-commerce presence. In fact, one of the major mail order players has recently reported revenues of $f^{2} \mathrm{~m}$ per month from its Internet business alone. Of course, the considerable advantage which traditional mail order companies - from consumer catalogues to office equipment suppliers - have over start-up dotcoms is their mature and reliable fulfilment infrastructure. More than this, it is a little mentioned fact that experienced mail order companies are past masters at managing their customers' expectations. In other words, they do not promise their customers service levels which cannot be reached, a matter which nine times out of ten focuses on delivery timing and accuracy.

\section{DATA ACCURACY}

This leads to the first data-based issue to be considered. Whether a company is starting a new web business, or it is taking an existing operation onto the Internet, a major development in data accuracy presents itself. If customers are placing orders over the phone, it is very difficult to prove they (or the telephone staff) have made a mistake or an inaccuracy when they ordered. This results in a considerable extra cost to the business in returns and complaints investigation. On the other hand, if the customer is filling in a web form (effectively processing their own order) then not only can a company save on a lot of staff time, but no longer can anyone make a mistake in the order details but the customers themselves.

\section{IMPERSONAL BUSINESS TRANSACTIONS}

Next, it is important to consider a rather obvious truth which, nevertheless, remains little discussed. Internet business is very impersonal. There is no longer any personal, or even telephone, contact between vendor and customer. This puts even more pressure on the vendor to use their own customer data, plus rich third party information sources, to try and personalise the customer's online experience. Champions of online marketing would say that this gives companies the opportunity to serve up pages personalised to each individual customer. If this is the case, however, why are so few online businesses doing so in a way which fulfils a sensible marketing objective?

The fact is that much 'personalisation' is not particularly clever or productive (marketing and direct marketing are, after all, meant to deliver a measurable commercial return). Take one, almost iconic, symbol of web success, an online book retailer. Each time a customer logs in, the website suggests further items in categories where he or she has previously bought. It does this in a blanket fashion, however, which is fine if it is the customer's favourite authors. But if he or she has previously bought a definitive book on Italian cooking, an encyclopaedia of family health, or a complete home DIY manual, it will 
suggest more of the same. This is not very intelligent use of a selling opportunity.

\section{CROSS-SELLING AND UP-SELLING SYSTEMS}

The next point of data-based investment to consider is the kind of clever systems which trigger up-sell or cross-sell suggestions based on third party data which allow companies to try and gain greater share of customer. In the business-to-consumer area, this would be based on scores utilising geodemographics, lifestyle, credit and other financial data. In business-tobusiness, business geodemographics and financial data are also available, as well as rich specialist data sources for particular target customer industries, but companies usually will also have to invest in some bespoke teleresearch to obtain the most powerful model and prospect pool.

As the pressure increases for online business to conduct its database marketing more professionally, the validation and credit information industries should receive an enormous boost (so long as, that is, they make their products easily and economically available in real time). According to Fletcher Research, whereas at the end of 1999 only 0.25 per cent of retail sales were conducted over the Internet, this will rise to a predicted 7.5 per cent in 2005. This inevitably means that the spectre of online consumer fraud (in the worst cases) and bad debt (just as importantly) will have to be countered - another area of data-based investment for web-based business. In consumer business, name and address validation will therefore assume increasing importance, and in business-to-business, universal and industry-specific datasets will be used, not merely to enrich targeted marketing but also to validate that a customer (a) exists and (b) is worth doing business with.

\section{GEOGRAPHY}

Two further discussions are worth covering briefly. First, is the interesting question as to whether geography will be as important to online business as it currently is in offline commerce. Almost all targeting is focused on postcode geography. The whole science of geodemographics and modelling works on the theory that similar people live in similar areas. Equally, geodemographics has been successfully applied to mass business marketing. But what happens when companies are conducting commerce online? People's (and businesses') e-mail addresses do not have this geographical constituent. In fact, e-mail by its very definition (access anywhere there is an available telephone line) positively eschews traditional geography. Yet it has already been stated that Internet business is an impersonal affair which demands that the online vendor, if anything, needs to concentrate more on targeting than its bricks and mortar equivalent. As a result, individual data, whether applied to the consumer or the business arena, assume an even greater importance. This is a dilemma in a world where Internet users often jealously guard their quasi-anonymity with vendors.

Current developments in 'permission marketing', where people self-define the subjects on which they are prepared to receive advertising messages — usually by e-mail, may well be paramount. It is fascinating that permission marketing is a notion that is already making commercial inroads in the consumer arena (through schemes like Mypoints, Myoffers, Ipoints, etc.) and yet has still to emerge in a concerted fashion in business-to-business. This is a shame, all too often initiatives 
in the business-to-consumer arena would have made a more viable impact if first launched into the world of business-tobusiness.

\section{CONCLUSION}

The conclusion of this paper must be that all too few online ventures have a sufficient data-basis, whether for the purposes of fulfilment, targeting or the increasing requirement for fraud prevention. The data sources, both in-house or third party, are there. But they are all too infrequently applied. Those who ignore the fact that any successful modern business must look to its data-basis, consumer or business-tobusiness, run the significant risk of joining the mounting list of casualties, both in pure dotcom companies and in those disappointing the financial markets in their attempts to web-enable their traditional operations. 